\title{
ArcheoSciences
}

Revue d'archéométrie

\section{Archaeometric data on production and circulation of Neolithic Serra d'Alto ware in southern Italy during the fifth millennium $\mathrm{BC}$}

Données archéométriques sur la production et la circulation des céramiques néolithiques de Serra d'Alto dans le Sud de l'Italie au cours du cinquième millénaire av. J.-C.

Italo M. Muntoni and Rocco Laviano

\section{(2) OpenEdition}

\section{Electronic version}

URL: https://journals.openedition.org/archeosciences/1032

DOI: 10.4000/archeosciences.1032

ISBN: 978-2-7535-1597-0

ISSN: $2104-3728$

\section{Publisher}

Presses universitaires de Rennes

\section{Printed version}

Date of publication: 31 December 2008

Number of pages: $125-135$

ISBN: 978-2-7535-0868-2

ISSN: 1960-1360

\section{Electronic reference}

Italo M. Muntoni and Rocco Laviano, "Archaeometric data on production and circulation of Neolithic Serra d'Alto ware in southern Italy during the fifth millennium BC", ArcheoSciences [Online], 32 | 2008, Online since 31 December 2011, connection on 01 February 2022. URL: http://

journals.openedition.org/archeosciences/1032 ; DOI: https://doi.org/10.4000/archeosciences. 1032 


\title{
Archaeometric data on production and circulation of Neolithic Serra d'Alto ware in southern Italy during the fifth millennium $\mathrm{BC}$
}

\author{
Données archéométriques sur la production et la circulation des céramiques \\ néolithiques de Serra d'Alto dans le Sud de l'Italie \\ au cours du cinquième millénaire av. J.-C.
}

\author{
Italo M. Muntoni* and Rocco Laviano**
}

\begin{abstract}
Mid/Late Neolithic Serra d'Alto ware was widely diffused in southern Italy during the fifth millennium BC and shows homogeneous formal and technical features. Its wide distribution and frequent occurrence in funerary or cultual contexts have led many scholars to emphasise its exchange value. The issue of the circulation of finished pots rather than of a production model in different areas of Southern Italy, is explored by means of petrologic, mineralogical and chemical analyses of pottery samples from Apulia, Basilicata and Calabria. The mineralogical and chemical components of the Apulia and Basilicata samples fit very well with those of the Plio-Pleistocene silty clays of the Bradanic Trough, although major and trace element concentrations are significant in distinguishing different sub-groups of pottery related to their precise geographical setting. Calabrian pottery shows the exploitation of a local non-Apulian clay source. The strong similarities in technological processes and the formal analogies between pots found at distant Neolithic sites all over southern Italy does not correspond, then, to an actual exchange of finished pots produced in Apulia or Basilicata. A large network of middle-distance exchange of formal and technological models of production, between many Neolithic sites located in different geographical areas, is therefore proposed.
\end{abstract}

Résumé : Les céramiques Serra d'Alto du Néolithique moyen-final sont largement répandues dans le Sud de l'Italie au Vème millénaire av. J.-C. et présentent des caractéristiques de formes et de techniques homogènes. La large diffusion de ce type de céramique et sa présence fréquente dans des contextes funéraires ou cultuels soulignent l'importance de sa valeur d'échange. La question de la circulation dans différentes régions du Sud de l'Italie de vases finis plutôt que de modèles de production est étudiée par des analyses pétrologiques, minéralogiques et chimiques d'échantillons venant des Pouilles, de Basilicate et de Calabre. Les composants minéralogiques et chimiques des échantillons provenant des Pouilles et de Basilicate correspondent bien à ceux des argiles silteuses du Plio-Pléistocène de la Fosse Bradanique, bien que la concentration en éléments majeurs et en éléments traces permette de différencier significativement des sous-groupes de poteries en fonction de leur aire géographique. La poterie de Calabre montre l'exploitation d'une source d'argile locale différente de celle des Pouilles. Les fortes analogies entre les procédés technologiques et les analogies de formes entre des vases trouvés sur des sites néolithiques distants dans tout le Sud de l'Italie ne correspondent alors pas à un réel échange de vases finis produits dans les Pouilles ou en Basilicate. Un riche réseau de moyenne distance d'échanges de modèles de production technologiques et de forme, entre de nombreux sites néolithiques situés sur différentes aires géographiques, est donc envisagé.

Keywords: Exchange, Italy, Neolithic, Raw materials, Serra d'Alto ware, Technology

Mots clés : Céramique Serra d'Alto, Échanges, Italie, Matières premières, Néolithique, Technologie

* Facoltà di Scienze Matematiche, Fisiche e Naturali - Università degli Studi di Bari; Facoltà di Scienze Umanistiche, Università di Roma "La Sapienza", Italy.(Italo.Muntoni@uniroma1.it)

** Dipartimento Geomineralogico - Università degli Studi di Bari, Via E. Orabona 4, 70125 Bari, Italy. (rocco.laviano@geomin.uniba.it) 


\section{THE SCIENTIFIC PROBLEM}

Mid-Late Neolithic Serra d'Alto ware was widespread in south-eastern Italy during the fifth millennium BC and exhibited homogeneous formal and technical features (Geniola, 1987; Cassano, 1993). It largely consisted of fine depurated pottery (figulina), painted with complex geometrical motifs (spirals, meanders, lattices, etc.) in dark brown, and with ribbon handles often surmounted by plastic appendices (Fig. 1). Serra d'Alto pottery takes its name from the eponymous prehistoric settlement on a small hill near Matera (Basilicata) where it was first identified (Ridola, 1924-1926; Lo Porto, 1989).

From a chronological point of view, this facies corresponds to the fifth millennium cal. BC: this can be seen (Laviano $\&$ Muntoni, in press) from the ancient ${ }^{14} \mathrm{C}$ dates from Masseria Candelaro (Apulia), Santa Barbara (Apulia) and Stretto Partanna (Sicily) to the late dates from Cala Scizzo (Apulia), Cala Colombo (Apulia) and Skorba (Maltese Islands). During this period, Serra d'Alto ware retained its main typological features while spreading through the southeastern Italian regions, where it mainly concentrated in the Murge and Matera areas as well as in Sicily and the Aeolian islands, and even in northern Italy (Mottes, 2002). A considerable amount of archaeological data shows economic and social transformations in the Neolithic communities of southern Italy related to changed environmental exploitation, the inception of ritual and funerary practices, and the diffusion/exchange of a class of painted fine ware (Cassano, 1993). The spread of Serra d'Alto pottery, which shows a significant technological improvement in pottery manufacture, is then a fundamental archaeological feature of the middle and late phases of the Neolithic in southern Italy.

This class of painted fine ware, which in some regions (Apulia and Basilicata) was produced in great quantities, indicates that forming, finishing and firing techniques had greatly improved compared to Early Neolithic pottery production. It may be that such technological improvements were also accompanied by the transformation in the social model of production, which may have shifted from the family to the village. In addition, the wide distribution of Serra d'Alto ware from the Dalmatian coast (Benac, 1975) to the Maltese Islands (Trump, 1966), with its frequent occurrence in funerary or cultual contexts, has led many scholars (i.e. Malone, 2003) to emphasise its exchange value, supposing that it would be exchanged between different groups: this ware was a prestige good in a large network of short- and middle-distance exchange.

\section{The ARCHAEOLOGICAL QUeSTIONS}

In the light of the above-mentioned archaeological problem of the relevance of Neolithic Serra d'Alto pottery, the investigation presented here, in the framework of a more extended research project (Muntoni, 2003; Laviano \& Muntoni, 2006; Laviano \& Muntoni, in press), aims to collect information about how and where such fine wares were produced.

The main archaeological questions that have been posed are:

a) Which technological choices - relating to raw materials, clay preparation (sieving, levigation, etc.) and firing (type of kiln, oxidising or reducing atmosphere, and firing temperature) - were selected at each site by ancient potters in order to produce the painted fine wares?

b) Does this pottery represent a significant technological shift in comparison to preceding ceramic productions?

c) Do formal analogies between pots found at distant Neolithic sites all over south-eastern Italy correspond to actual exchanges of technological models and/or selected raw materials and/or finished pots?

\section{Archaeological sampling AND ANALYTICAL METHODS}

Samples were selected from Neolithic villages located in different areas of southern Italy which correspond to different clay deposits. Neolithic settlements or caves were selected, which are recently excavated or where excavations are taking place, involving various institutions who operate in the research area (Rome, Bari, Pisa and Genoa Universities, the Soprintendenza per i Beni Archeologici della Puglia, the Soprintendenza per i Beni Archeologici della Basilicata, the Museo Preistorico Etnografico "L. Pigorini" of Rome). As far as the sample selection from site complexes is concerned, only sites where reliable stratigraphic sequences have been uncovered, and where functional and chronological contexts have been identified, were selected. Potsherds were selected following a macroscopic classification previously carried out on the basis of wall thickness, granulometry, and surface treatments and decorations. As finds were often too fragmentary, pot form was not included in the evaluation parameters at this stage of research. The size of the samples allowed part of the potsherds to be preserved for checks after the analyses, if necessary.

Mineralogical studies were carried out by PXRD using a Philips diffractometer (PW 1710) with Ni-filtered Cu $\mathrm{K} \alpha$ radiation and employing $\mathrm{NaF}$ as the internal standard. 


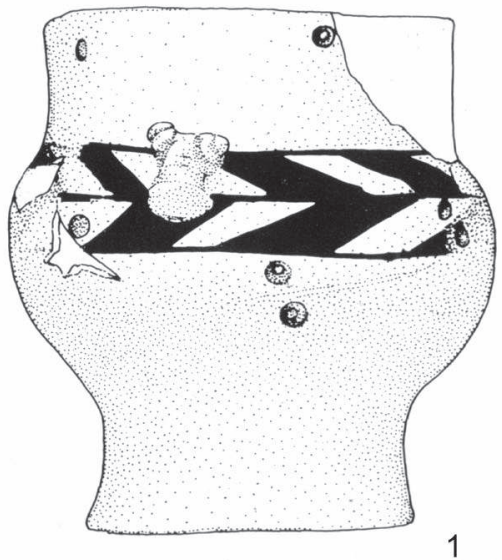

1

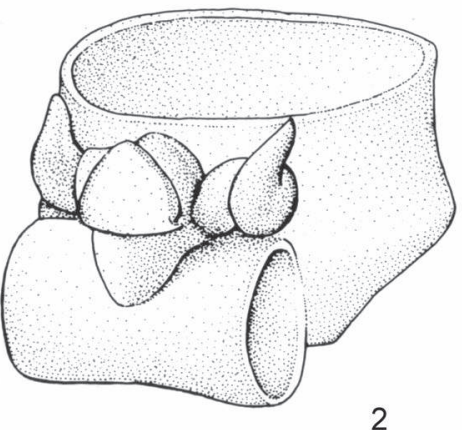

2

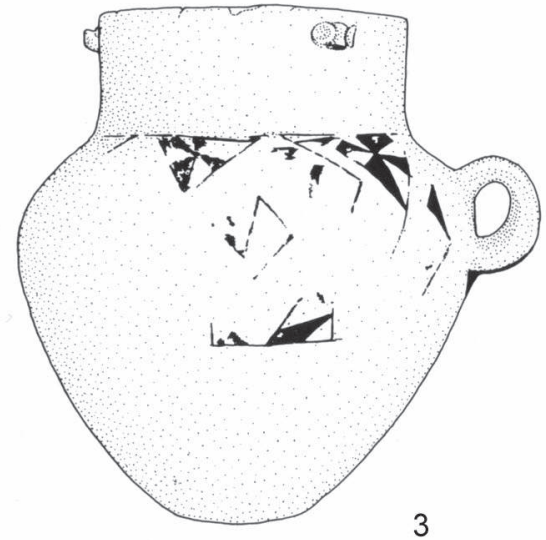

3
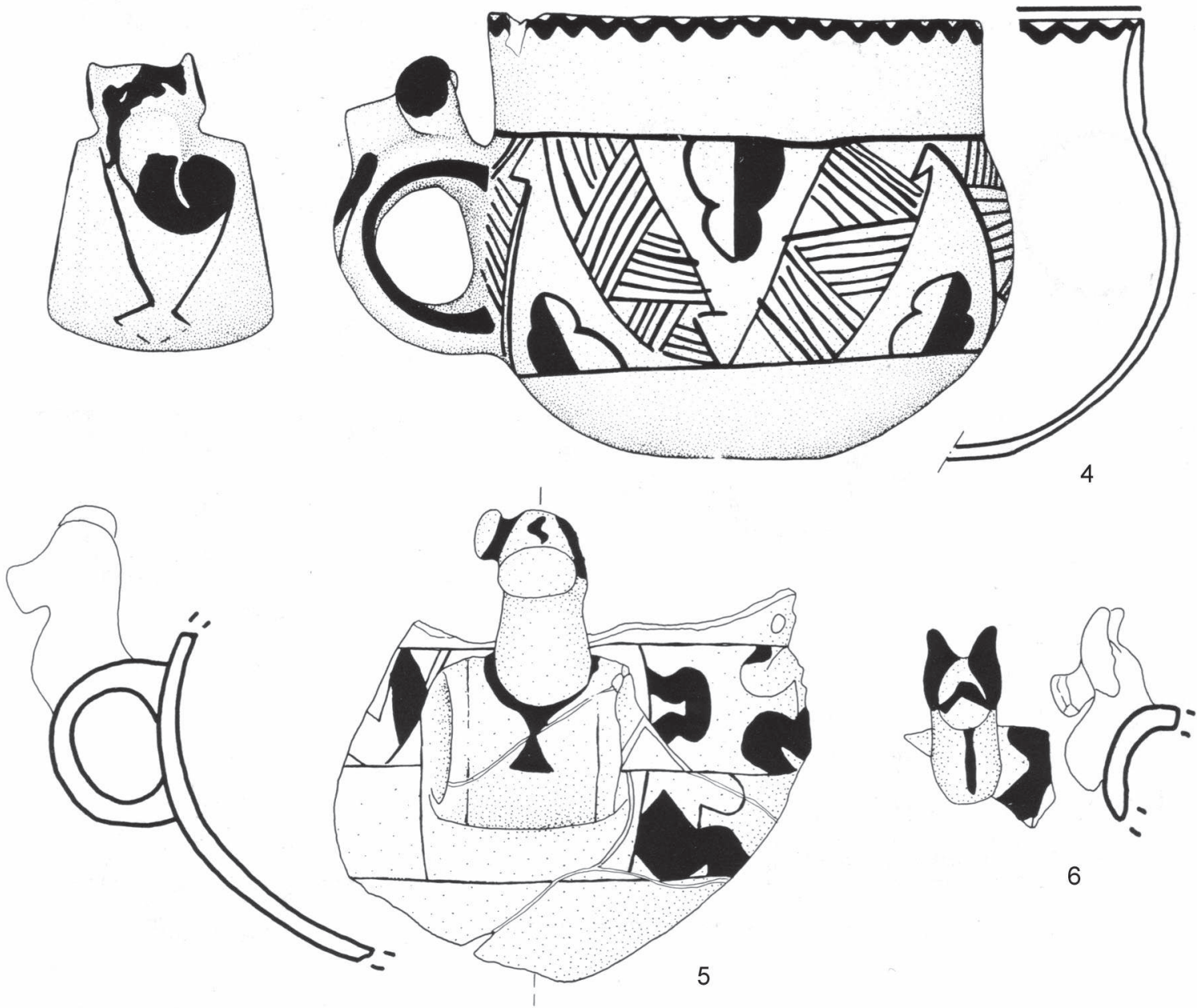

6

Figure 1: Examples of Serra d'Alto pots from Neolithic villages in Apulia and Basilicata: (1) Pulo di Molfetta (BA); (2) Setteponti (Matera); (3) Serra d'Alto (Matera); (4) Masseria Candelaro (Manfredonia - FG); (5-6) Scamuso (Mola di Bari - BA) (1-3: scale 1:5, 4-6: scale 1:2; after Cassano 1993, figs. 3 and 7).

Figure 1 : Exemples de vases de Serra d'Alto provenant de villages Néolithiques des Pouilles et de Basilicate: (1) Pulo di Molfetta (BA); (2) Setteponti (Matera); (3) Serra d'Alto (Matera); (4) Masseria Candelaro (Manfredonia - FG); (5-6) Scamuso (Mola di Bari-BA) (1-3 : échelle 1:5, 4-6: échelle 1:2; d'après Cassano 1993, fig. 3 et 7). 
Petrological observation was made on thin sections with a polarized light microscope (OM). Major and trace element determination was performed by XRF, using a Philips PW 1480/10 spectrometer ( $\mathrm{Cr}$ anode for major and minor elements, $\mathrm{Rh}$ anode for $\mathrm{Rb}, \mathrm{Sr}, \mathrm{Y}, \mathrm{Zr}, \mathrm{Nb}$ and $\mathrm{W}$ anode for $\mathrm{Ce}$, $\mathrm{La}, \mathrm{Ba}, \mathrm{Ni}, \mathrm{Cr}, \mathrm{V})$, following analytical techniques outlined by Franzini et al. (1972; 1975) and Leoni \& Saitta (1976). About $5 \mathrm{~g}$ of representative powder from each sample was subjected to XRF. Two reference standards (AGV-1 from USGS - USA and NIM-G from NIM - South Africa) were used to check the accuracy of the analytical data. Loss on ignition was determined by heating the samples at $1,000^{\circ} \mathrm{C}$ for 12 hours; then PXRD patterns of these heated samples were recorded at room temperature, for the identification of mineralogical changes.

\section{TeChNOLOGY}

With regard to the first two archaeological questions (Which technological choice? How does it relate to previous Early and/or Mid-Neolithic pottery production?), sampling was begun in Apulia and Basilicata. Serra d'Alto ware was largely concentrated in these regions and technological data have been previously collected on Early Neolithic wares there, as well as the bichrome fine wares of Mid-Neolithic production which were earlier than the Serra d'Alto ware (Muntoni, 2003; Cassano et al., 2004).

\section{Archaeological contexts and geology of the area}

A large set of 112 pottery samples have been analysed from 12 excavated Neolithic villages or caves located in different sub-geographical areas (Tavoliere, Murge and the Bradanic Trough) in Apulia and Basilicata (Fig. 2). The sampled sites are Masseria Candelaro on the Tavoliere plain (Cassano et al., 1994-1995; Cassano et al., 2004); Setteponti along the Ofanto river valley (Muntoni et al., 2006); Pulo di Molfetta (Laviano \& Muntoni, 2003), Grotta Scanzano and Grotta della Tartaruga (Muntoni et al., 2006), Cala Colombo (Dell'Anna \& Laviano, 1994), Madonna delle Grazie and Torre delle Monache (Dell'Anna \& Radina, 1994; Laviano et al., 2008), Santa Barbara (Geniola et al., 2005) along the Adriatic coast of the Murge plateau; and Serra d'Alto, Trasano and Masseria Fragennaro (Muntoni et al., in press) in the Bradanic Trough.

The Tavoliere plain, the most extensive in southern Italy, is a Mesozoic-Palaeogene limestone depression filled with marine deposits of Plio-Pleistocene silty clay (Bradanic cycle), often overlain by post-Calabrian marine sands (ter- raced marine deposits), Upper Pleistocene terraced alluvial deposits, and Holocene alluvial and lacustrine deposits of continental origin. The large geologically homogeneous Murge plateau is formed by the Mesozoic limestone formations of Calcare di Bari and Calcare di Altamura, bordered by Bradanic (Pliocene-Lower Pleistocene) and Quaternary Terraced Marine deposits.

Marine Plio-Pleistocene clays of the Bradanic cycle, also known as Argille Subappennine, crop out along the western margin of the Tavoliere plain and the Murge plateau (Dell'Anna \& Laviano, 1991). The clays consist of silty clay or clayey silt, with little sand, and have very similar mineralogical compositions (clay minerals, carbonates, quartz and feldspars). The clay minerals are a mixture of $2 \mathrm{M}$ illite, Mg-bearing smectite, Fe-bearing chlorite, kaolinite and randomly interstratified illite-smectite with 30-70\% montmorillonite-like layers. Natural non-plastic material consists of carbonates (calcite, as bioclastic or detrital granules, and dolomite), quartz and feldspars (orthoclase, microcline and $\mathrm{Na}$-plagioclase). These clays are characterized by the relative abundance of $\mathrm{SiO}_{2}, \mathrm{Al}_{2} \mathrm{O}_{3}, \mathrm{CaO}, \mathrm{Fe}_{2} \mathrm{O}_{3}, \mathrm{~K}_{2} \mathrm{O}$ and $\mathrm{MgO}$. Due to their mainly calcareous composition (up to $17 \mathrm{wt} \%$ $\mathrm{CaO}$ ), they can be classified as marly clays. In general, clay fractions $(<2 \mu \mathrm{m})$ have a lower $\mathrm{CaO}$ content than the whole specimens, whereas the $\mathrm{Al}_{2} \mathrm{O}_{3}$ and $\mathrm{Fe}_{2} \mathrm{O}_{3}$ concentrations are higher.

\section{Results}

Thin section analyses of Serra d'Alto ware samples show a very fine paste texture, with a fairly fat clay matrix; out of the sheet silicates only mica crystals are recognizable (Fig. 3: a-c). Non-plastic inclusions are homogeneous finegrained $(\leq 150 / 200 \mu \mathrm{m})$ quartz, scarce calcareous clasts and carbonate fossils (mainly benthonic Foraminifera and rare molluscs). Clasts of feldspars and iron oxides or hydroxides are also present. Primary porosity and drying shrinkage are generally low. Textural features and low birefringence relate to a high synterization grade.

Mineralogical analyses (PXRD) show the presence of predominant quartz, with small quantities of K-feldspar, plagioclase, and a variable amount of calcite. Weak peaks of clay minerals were observed only in some samples from the Adriatic coasts. Only very weak peak of micas at $10 \AA$ was detected in almost all samples. The occurrence of new phases, such as diopsidic pyroxenes, gehlenite and hematite, was frequently observed in samples from the Adriatic coast of the Tavoliere and Murge, and was always seen in those from the Bradanic Trough (Fig. 4). PXRD analyses of heat-treated samples at $1,000^{\circ} \mathrm{C}$ confirm the presence of pre- 
Figure 2: Geological sketch map of south-eastern Italy (modified after Sella et al., 1988) with location of sampled Mid-Neolithic settlements: (1) Masseria Candelaro; (2) Setteponti; (3) Pulo di Molfetta; (4) Grotta Scanzano; (5) Grotta della Tartaruga; (6) Cala Colombo; (7) Madonna delle Grazie; (8) Torre delle Monache; (9) Santa Barbara; (10) Serra d'Alto; (11) Trasano; (12) Masseria Fragennaro.

Figure 2: Carte géologique simplifiée du Sud-est de l'Italie (modifiée d'après Sella et al. 1988) avec emplacement des sites du Néolithique moyen échantillonnés: (1) Masseria Candelaro; (2) Setteponti; (3) Pulo di Molfetta; (4) Grotta Scanzano; (5) Grotta della Tartaruga; (6) Cala Colombo; (7) Madonna delle Grazie; (8) Torre delle Monache; (9) Santa Barbara; (10) Serra d'Alto; (11) Trasano; (12) Masseria Fragennaro.

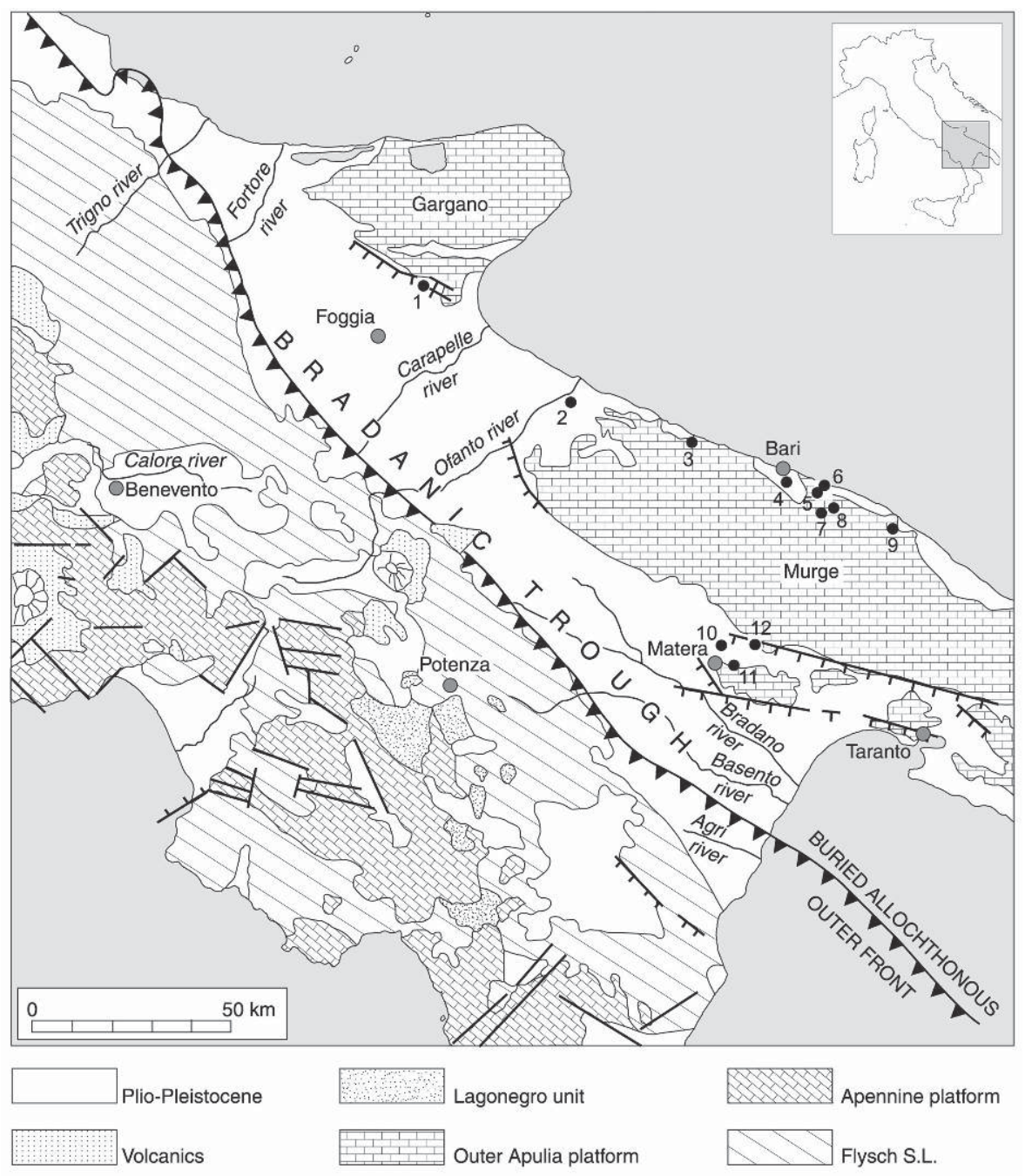

dominant quartz, while feldspars increase in concentration. The presence of a high quantity of neoformed pyroxenes, gehlenite and hematite was detected in all samples.

XRF chemical analyses evidenced that the main oxides are $\mathrm{SiO}_{2}(\bar{x}=45-50 w t \%), \mathrm{Al}_{2} \mathrm{O}_{3}(\bar{x}=11-14 w t \%)$ and $\mathrm{CaO}(\bar{x}=12-20 w t \%)$, with some variations with regards to the $\mathrm{CaO}, \mathrm{Na}_{2} \mathrm{O}, \mathrm{K}_{2} \mathrm{O}$ and $\mathrm{MgO}$ percentages, related to the main quantities of clay minerals, gehlenite, feldspars and diopsidic pyroxenes. All samples are Ca-rich. The ceramic phase diagram shows an almost complete overlap of the samples in the central section, corresponding to the chemical composition of Plio-Pleistocene Apulian silty clays (Fig. 5). A few samples from the Bradanic Trough are characterized by high Ca contents, related to very large quantities of calcite, whereas others from the northern Murge have smaller quantities. However, some bivariate plots with different major and trace elements ratios are important in some cases for distinguishing samples from neighbouring sites located within the same sub-area. For example, bivariate plots can be used for the area on the Adriatic coast south of Bari (Fig. 6: a-b) to distinguish between Grotta della Tartaruga and Cala Colombo (Torre a Mare), $1 \mathrm{~km}$ away from each other; or between Santa Barbara (Polignano a Mare) and Madonna delle Grazie plus Torre delle Monache (Rutigliano), $20 \mathrm{~km}$ away from each other. In addition, the bivariate plot $\mathrm{SiO}_{2} / \mathrm{Al}_{2} \mathrm{O}_{3} v s$. $\mathrm{Na}_{2} \mathrm{O} / \mathrm{K}_{2} \mathrm{O}$ of samples from the two sites of Serra d'Alto and Trasano (in the Bradanic Trough) shows two clusters with a very limited overlapping area (Fig. 6: c). The two samples, one from Trasano and one from Serra d'Alto, which fall within the cluster of the neighbouring site, could also be interpreted as pots imported from one site to the other. Trace element concentrations also confirm the homogeneity of the samples; this finding agrees with the geochemical homogeneity of the Plio-Pleistocene Apulian marly clays. Nevertheless some elements, such as La, Y, 

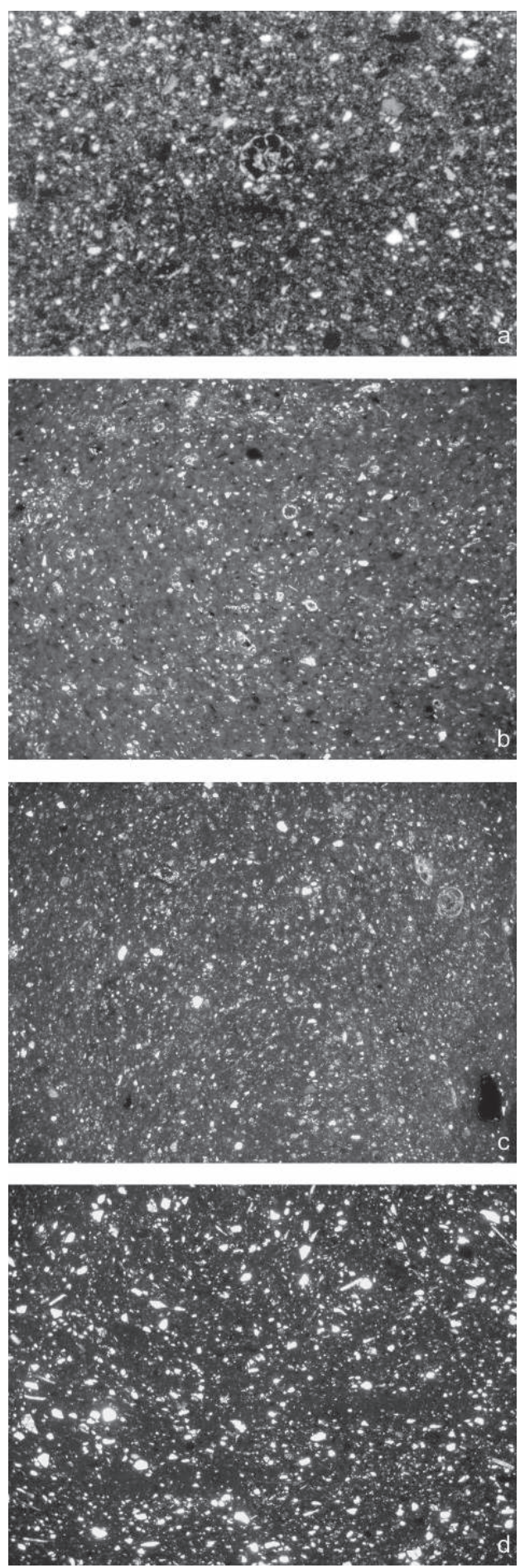

Figure 3:Thin section photographs of fine ware samples from different sites: (a) SP12; (b) TM74; (c) SdA09; (d) FAV42 (the frame length is $4 \mathrm{~mm}$; a-c: crossed polarized light; $\mathrm{d}$ : plain polarized light).

Figure 3 : Photographies en lame mince des échantillons de céramique fine provenant de différents sites: (a) SP12; (b) TM74; (c) SdA09; (d) FAV42 (la longueur des cadres est de $4 \mathrm{~mm}$; a-c: lumière polarisée et analysée; $d$ : lumière polarisée).

\begin{tabular}{|c|c|c|c|c|}
\hline \multirow{3}{*}{$\begin{array}{l}\text { Minerals } \\
\text { C.M. }\end{array}$} & \multicolumn{4}{|c|}{ Sampling areas } \\
\hline & \multicolumn{2}{|c|}{ Adriatic coast } & \multirow[t]{2}{*}{ Bradanic Trough } & \multirow[t]{2}{*}{ Plain of Sibar } \\
\hline & ........... & & & \\
\hline Micas & 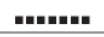 & ............ & ............ & ............ \\
\hline Qtz & שصصघ & שصصص & صEص & שصصص \\
\hline Kfs & 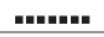 & 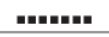 & 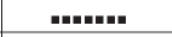 & - \\
\hline Pl & ........... & ........... & ........... & ........... \\
\hline Cal & ص日ص & ............ & ........... & \\
\hline $\mathbf{P x}$ & & - & - & 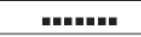 \\
\hline Gh & & 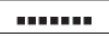 & | & ........... \\
\hline Hem & & ........... & & ........... \\
\hline $\begin{array}{l}\text { estimated } \\
\mathbf{T}^{\circ} \mathbf{C} \text { ranges } \\
\end{array}$ & $<750$ & $850-1,050$ & $800-1,000$ & $900-1,000$ \\
\hline $\begin{array}{l}\text { analysed } \\
\text { samples }\end{array}$ & 22 & 50 & 40 & 15 \\
\hline
\end{tabular}

Figure 4: The different phase associations, detected by PXRD, with the estimated ranges of firing temperatures for the analysed Serra d'Alto ware samples from sites related to different geological areas. The dimension of squares is related to mineralogical phase abundance. Key: C.M. = clay minerals; Micas = muscovite + biotite; Qtz = quartz; Kfs = K-feldspar; $\mathrm{Pl}$ = plagioclase $\mathrm{Cal}=$ calcite; $\mathrm{Px}=$ pyroxene; $\mathrm{Gh}=$ gehlenite; Hem = hematite (symbols as in Kretz 1983).

Figure 4 : Les différentes associations de phases, mises en évidence par PXRD, avec les intervalles de températures de cuisson estimées pour les échantillons de céramique Serra d'Alto. Les sites de provenance des céramiques se trouvaient sur des différents substrats géologiques. La dimension des carrés est reliée à la richesse minéralogique de la phase. Légende: C.M. = minéraux des argiles; Micas = muscovite + biotite; $Q t z=$ quartz; $K f s=K$-feldspath; $P l=$ plagioclase $;$ Cal = calcite $; P x$ = pyroxène; $G$ h = gehlénite; Hem = hématite (symboles comme dans Kretz 1983).

$\mathrm{Rb}$ and $\mathrm{Nb}$ are important in some cases for distinguishing different sub-groups of samples from neighbouring sites located in the same sub-area (Fig. 7). The bivariate plots show a variable correlation, mainly in $\mathrm{La} v s$. $\mathrm{Rb}$ and $\mathrm{La}$ vs. Nb plots (Fig. 7: a, c), between the two trace elements considered. These data could suggest different exploitation sites and/or paste processing which may have occurred in different places with the same type of raw materials.

\section{Discussion}

Mineralogical and chemical data fit very well with those of the Plio-Pleistocene silty clay that crops out in many areas of northern and central Apulia, in some cases at great distances from the site (up to $30 \mathrm{~km}$ from some analysed sites). These clays were then used for the production of Serra d'Alto ware, even in sites where they could be considered non-local materials. Chemical data on Serra d'Alto pottery samples are important in distinguishing different sub-groups of pottery related to their geographical setting. It can be inferred that Serra d'Alto pottery was produced in more 


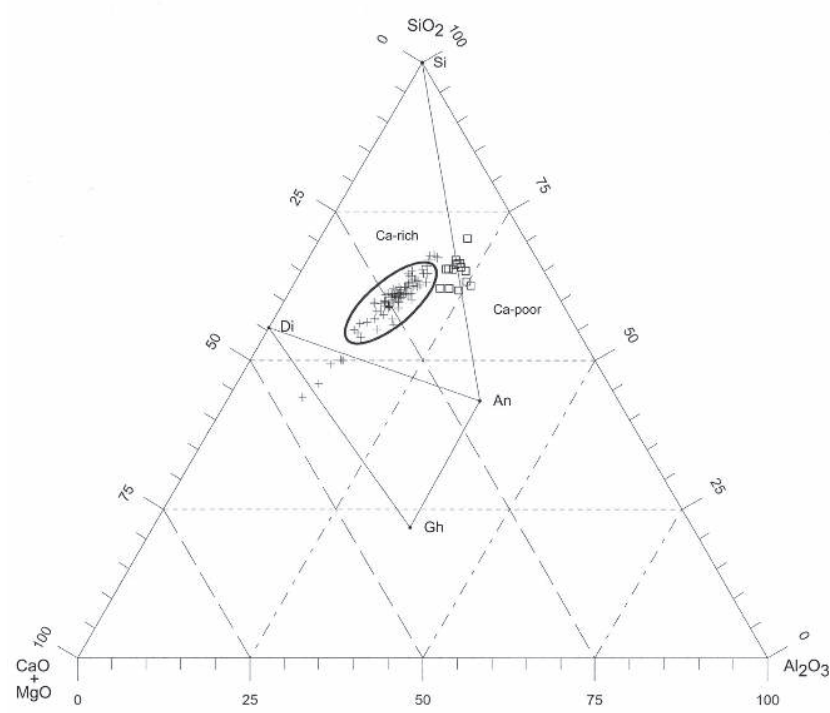

Figure 5: $(\mathrm{CaO}+\mathrm{MgO})-\mathrm{Al}_{2} \mathrm{O}_{3}-\mathrm{SiO}_{2}$ wt $\%$ diagram $(\mathrm{Di}=$ diopside; $\mathrm{Gh}=$ gehlenite; $\mathrm{An}=$ anorthite): Serra d'Alto samples (+) from Apulia and Basilicata, fine painted samples (squares) from the Plain of Sibari (northern Calabria), and the field defined by the samples of Plio-Pleistocene silty clays $(n=68)$ from the Bradanic Trough.

Figure 5: $(\mathrm{CaO}+\mathrm{MgO})-\mathrm{Al}_{2} \mathrm{O}_{3}-\mathrm{SiO}_{2}$ wt\% diagramme (Di = diopside; $G$ h = gehlénite; $A n=$ anorthite): échantillons de Serra d'Alto (+) venant des Pouilles et de Basilicate, échantillons de céramique fine peinte (carrés) venant de la Plaine de Sybaris (Nord de la Calabre), et le domaine défini par les échantillons d'argiles silteuses du PlioPléistocène (n=68) de la Fosse Bradanique.

than one centre and that finished pots were not exchanged between different archaeological sites. High temperatures have been suggested for these painted fine wares, revealing a better firing control (temperature, rate of heating and oxidising atmosphere) and the use of kilns. The gehlenite and pyroxene neoformations, only apparent by PXRD analysis, and the absent clay minerals suggest that temperatures between 850 and $1,050^{\circ} \mathrm{C}$ were obtained (Heimann \& Maggetti, 1981; Maggetti, 1981; Maggetti 1982). In the same groups decreasing amounts of calcite were seen, which was re-crystallized in pottery pores, as microscopic observation on thin section shows. The absence of a dark core and the low birefringence of the matrix confirm respectively an accurate oxidising atmosphere and a high degree of sintering. Only some samples from the Adriatic coasts could have been fired at lower temperatures, still not over $750{ }^{\circ} \mathrm{C}$, on the basis of the presence in X-ray patterns (Fig. 4) of weak peaks of some clay minerals together with the occurrence of primary calcite, as microscopic observation on thin section shows.
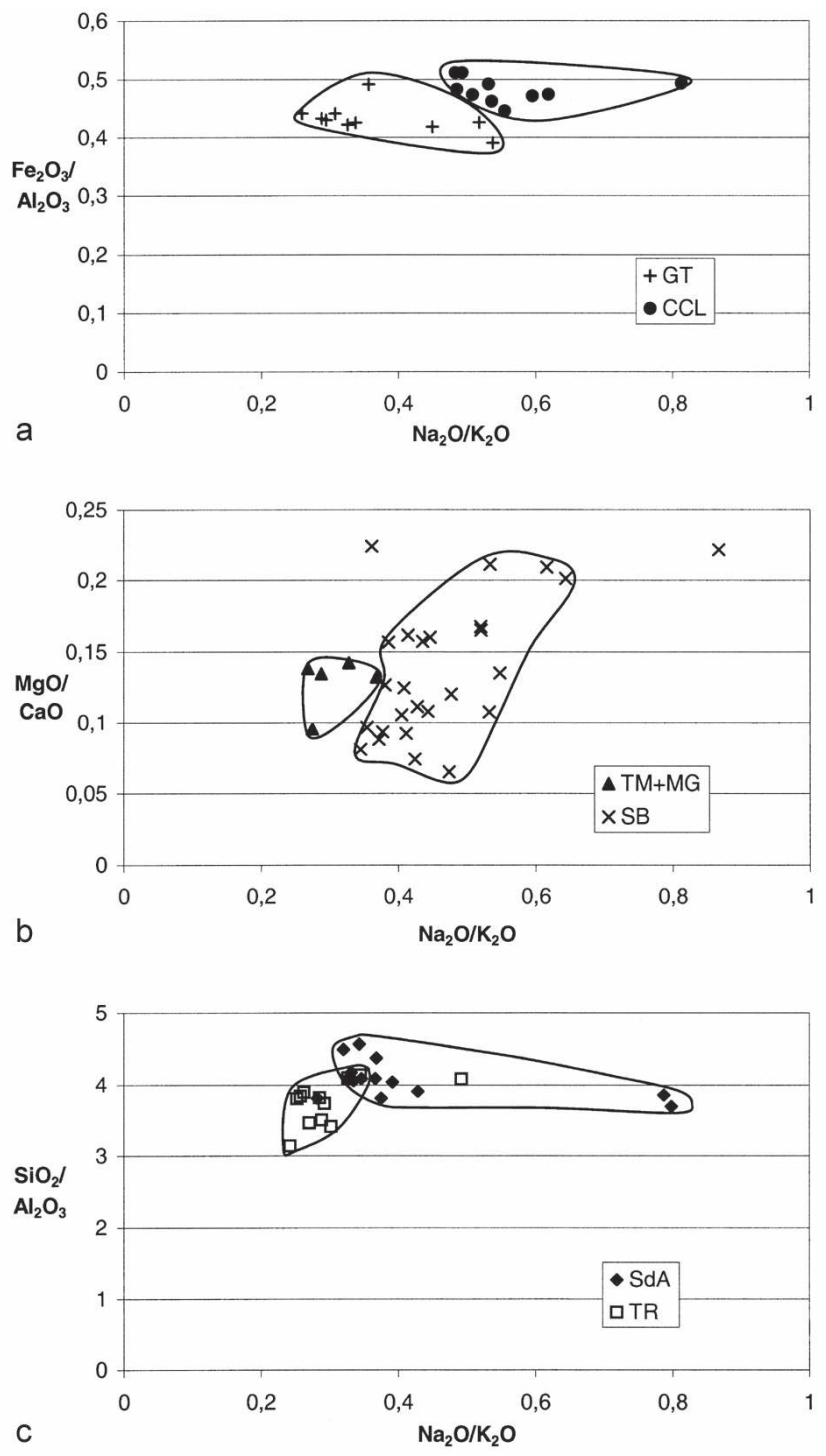

Figure 6: Bivariate plots (wt\%) which can distinguish samples from sites located within the same areas in Apulia or Basilicata: (a) $\mathrm{Fe}_{2} \mathrm{O}_{3} / \mathrm{Al}_{2} \mathrm{O}_{3}$ vs. $\mathrm{Na}_{2} \mathrm{O} / \mathrm{K}_{2} \mathrm{O}$ of samples from Grotta della Tartaruga (GT) and Cala Colombo (CCL); (b) $\mathrm{MgO} / \mathrm{CaO}$ vs. $\mathrm{Na}_{2} \mathrm{O} / \mathrm{K}_{2} \mathrm{O}$ of samples from Rutigliano area (TM+MG) and Santa Barbara (SB); (c) $\mathrm{SiO}_{2} / \mathrm{Al}_{2} \mathrm{O}_{3}$ vs. $\mathrm{Na}_{2} \mathrm{O} / \mathrm{K}_{2} \mathrm{O}$ of samples from Serra d'Alto (SdA) and Trasano (TR).

Figure 6 : Diagrammes bivariés (wt\%) permettant de différencier des échantillons provenant de sites situés dans les mêmes régions dans les Pouilles et en Basilicate: (a) $\mathrm{Fe}_{2} \mathrm{O}_{3} / \mathrm{Al}_{2} \mathrm{O}_{3}$ vs. $\mathrm{Na}_{2} \mathrm{O} / \mathrm{K}_{2} \mathrm{O}$ pour les échantillons provenant de la Grotta della Tartaruga (GT) et de Cala Colombo (CCL); (b) $\mathrm{MgO} / \mathrm{CaO}$ vs. $\mathrm{Na}_{2} \mathrm{O} / \mathrm{K}_{2} \mathrm{O}$ pour les échantillons provenant de la région de Rutigliano $(T M+M G)$ et de Santa Barbara (SB); (c) $\mathrm{SiO}_{2} / \mathrm{Al}_{2} \mathrm{O}_{3}$ vs. $\mathrm{Na}_{2} \mathrm{O} / \mathrm{K}_{2} \mathrm{O}$ pour les échantillons provenant de Serra d'Alto (SdA) et de Trasano (TR).

ArcheoSCiences, revue d'archéométrie, 32, 2008, p. 125-135 

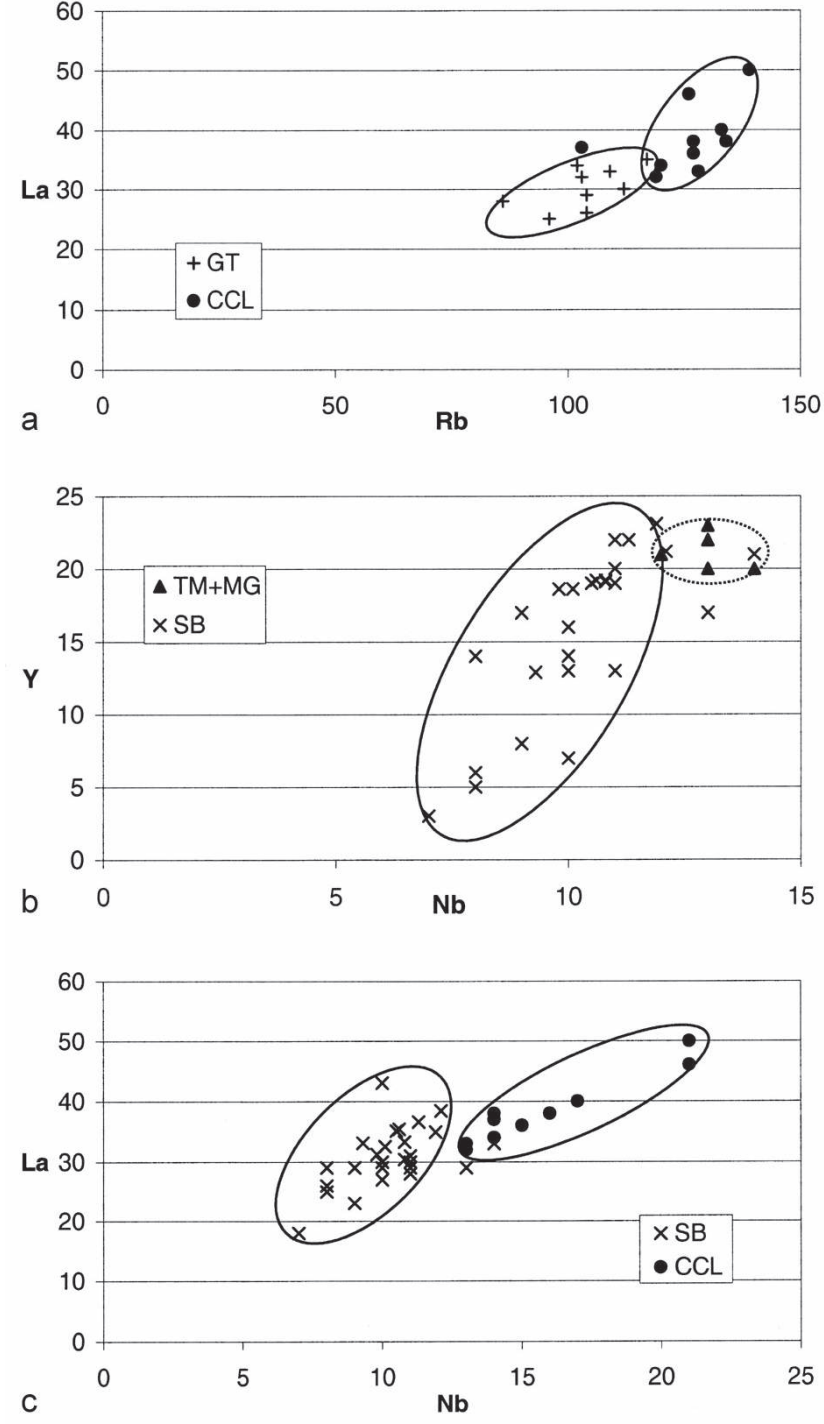

Figure 7 : Bivariate plots (ppm) which can distinguish samples from sites located within the same areas in Apulia or Basilicata: (a) La vs. Rb of samples from Grotta della Tartaruga (GT) and Cala Colombo (CCL); (b) Y vs. Nb of samples from Rutigliano area (TM+MG) and Santa Barbara (SB); (c) La vs. Nb of samples from Santa Barbara (SB) and Cala Colombo (CCL).

Figure 7: Diagrammes bivariés (ppm) permettant de différencier des échantillons provenant de sites situés dans les mêmes régions dans les Pouilles et en Basilicate: (a) La vs. Rb pour les échantillons provenant de la Grotta della Tartaruga (GT) et de Cala Colombo (CCL); (b) Y vs. Nb pour les échantillons provenant de la région de Rutigliano (TM+MG) et de Santa Barbara (SB); (c) La vs. Nb pour les échantillons provenant de Santa Barbara (SB) et de Cala Colombo (CCL).

\section{LONG-DISTANCE EXCHANGE?}

There has been some discussion (Malone, 2003) over the extent to which painted ceramics found outside Apulia and Basilicata might be exotic or imported, and to which they might have been a commodity for long-distance exchange. Two samples of painted fine ware were analysed in 1995 from the excavations at the Neolithic site of Capo Alfiere (carried out by the University of Texas at Austin), which is located on the eastern seaboard of Calabria. The two samples were considered as a probable import from further north and east in what is now Apulia and Basilicata (Morter \& Iceland, 1995).

Two different patterns of raw material provenance were evidenced through the archaeometric analyses of Sicilian Serra d'Alto pottery from the excavations in the Acropolis and Diana plain of the island of Lipari in the Aeolian Archipelago (Messina province), and from the excavations of the ditch at Stretto Partanna in south-western Sicily (Trapani province). Thin section analyses of 15 painted fine wares from Lipari (Williams, 1980; Williams \& Levi, 2001) show the systematic use of non-local marine clays cropping out in north-western Sicily. The sporadic presence of local volcanic non-plastic inclusions may also suggest a local production of some of these pots with imported raw materials. Archaeometric analyses (thin section, XRD and XRF) of six painted fine wares from Stretto (Di Martino et al., 2006; Farnetano et al., 2006) show that the dominant clastic and fossiliferous ( $\geq 30 \%)$ constituents are all compatible with the local Pleistocene grey clays cropping out in the site's hinterland.

In the light of this different pattern of raw materials procurement, it was decided to extend the pottery sampling and archaeometric analyses to Calabria (in collaboration with the University of Genoa and the Museo Preistorico Etnografico "L. Pigorini" of Rome), and to Sicily (in collaboration with the Soprintendenza Beni Culturali ed Ambientali of Messina). The project started with the Early and Mid/Late Neolithic open settlement of "Favella della Corte" (Corigliano Calabro, Cosenza Province) in the Plain of Sibari (Muntoni et al., 2007).

\section{Archaeological contexts and the geology of the area}

The Neolithic village of "Favella della Corte" is located on a fluvial terrace along the Crati river, at $20 \mathrm{~m}$ above sea level and some $5 \mathrm{~km}$ from the present-day Ionian coastline. Archaeological excavations, regularly carried out from 1990 to 2002 by the University of Genoa and the Soprintendenza 
al Museo Preistorico Etnografico "L. Pigorini” of Rome, identified two main occupation phases at the site, the earlier dated to the Early Neolithic and the later to the Mid/Late Neolithic. Very fine and smoothed pots, plain or painted brown ("figulina" or ware C), are typical of the village's Mid/ Late Neolithic cobble structures.

Around the site, alluvial deposits and Pleistocene deposits crop out: at the bottom they are composed of conglomerates, sands and blue-grey clays and, at the top, of sands and conglomerates. The geology of the area (Messina et al., 1994) is also characterised by Calabrian grey marly or silty clays, with sandy levels interbedded, and by the Paleozoic dioritic-kinzigitic outcrops of the Sila Massif, consisting mainly of plutonic igneous rocks and medium- to highgrade micaschists and gneisses.

\section{Results}

Non-plastic inclusions of the Mid/Late Neolithic pots ("figulina" ware) have dimensions in the range of 0.1-0.4 $\mathrm{mm}$ and are essentially quartz, muscovite and plagioclase (Fig. 3: d); a few samples also reveal the sporadic presence of grog. Mineralogical analyses confirm the presence of predominant quartz and K-feldspar, with a small quantity of plagioclase. The systematic occurrence of new phases, formed during firing, such as diopsidic pyroxenes, gehlenite and hematite, are detected (Fig. 4). Phase transformations were obviously fostered by the very fine paste texture. Firing temperatures were in a range of 900-1,000 ${ }^{\circ} \mathrm{C}$. XRF analyses are consistent with mineralogical data and show that $\mathrm{SiO}_{2}(\bar{x}=47.90 w t \%), \mathrm{Al}_{2} \mathrm{O}_{3}(\bar{x}=16.53$ $w t \%)$ and $\mathrm{Fe}_{2} \mathrm{O}_{3}(\bar{x}=6.96 w t \%)$ are the main oxides and $\mathrm{CaO}$ concentrations are low $(x=6.08 w t \%)$.

\section{Discussion}

Different $\mathrm{CaO}+\mathrm{MgO}$ and $\mathrm{Al}_{2} \mathrm{O}_{3}$ concentrations (Fig. 5) allow Mid/Late Neolithic samples $(\mathrm{n}=15)$ to be distinguished from Plio-Pleistocene Apulian silty clays ( $\mathrm{n}=68$ ). The concentration of trace elements (Fig. 8) is also very useful to show no affinity between Mid/Late Neolithic pottery samples $(\mathrm{n}=15)$ and Plio-Pleistocene Apulian silty clays $(\mathrm{n}=33)$. The suggestion of Morter \& Iceland (1995) that painted fine were found in Calabria could be a probable import from Apulia and Basilicata cannot therefore be confirmed. Mid/ Late Neolithic Calabrian pottery demonstrated the exploitation of a non-Apulian clay source, to be probably identified with the local Calabrian grey marly or silty clays (Dell'Anna \& Laviano, 1988). The formal analogies between pots found at distant Neolithic sites all over south-eastern Italy does not
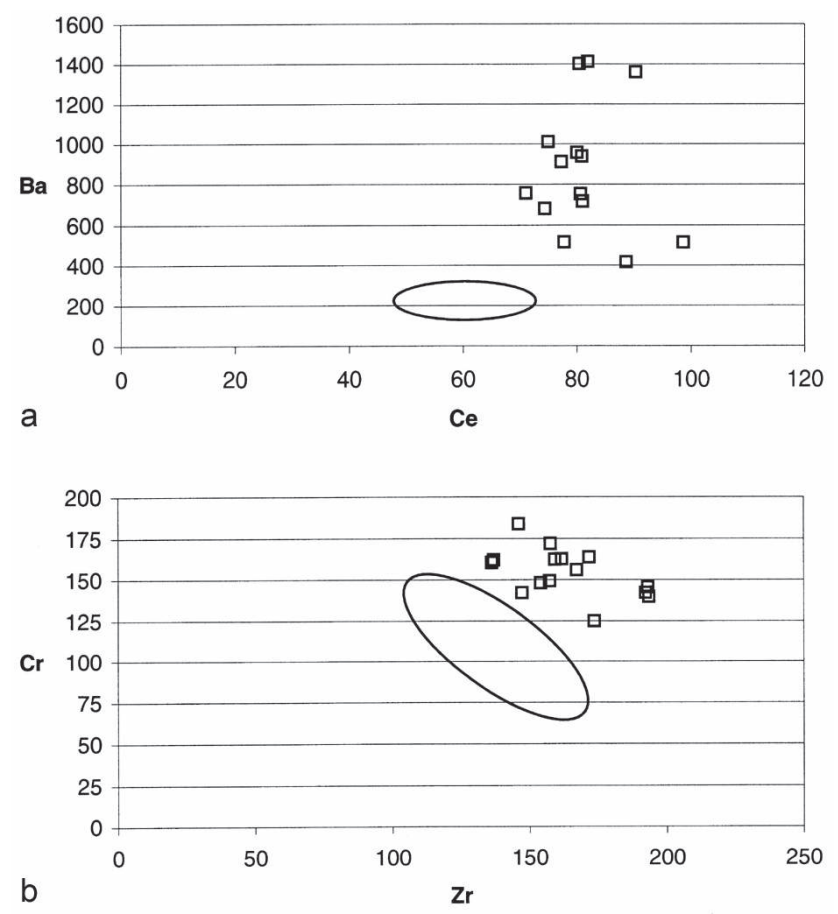

Figure 8: Bivariate plots (ppm) (a) Ba vs. Ce and (b) Cr vs. Zr of fine painted samples (squares) from the Plain of Sibari (northern Calabria), and the field defined by the samples of Plio-Pleistocene silty clays $(\mathrm{n}=33)$ from the Bradanic Trough.

Figure 8: Diagrammes bivariés (ppm) (a) Ba vs. Ce et (b) Crvs. $\mathrm{Zr}$ pour les échantillons de céramique fine peinte (carrés) provenant de la Plaine de Sybaris (Nord de la Calabre), et le domaine défini par les échantillons d'argiles silteuses du Plio-Pléistocène $(n=33)$ de la Fosse Bradanique.

correspond to an actual exchange of finished pots produced in Apulia. Also Malone's suggestion that painted fine wares may represent a commodity for long-distance exchange cannot therefore be confirmed.

\section{ConClusion}

Serra d'Alto pottery can therefore be seen as a significant technological shift compared to Early Neolithic ceramic productions (Laviano \& Muntoni, 2006), as suggested by the selection and supply of specific raw materials, the improvement in forming and finishing techniques and in firing technology. Bichrome and trichrome fine wares of Mid-Neolithic production that date to earlier than the Serra d'Alto ware (Laviano \& Muntoni, 2006) also show the same substantial change in the whole production sequence: these fine wares demanded high-quality clay and a particularly skilled technology of production, modelling, painting, and firing. 
The use of specific clay-beds shows a more complex clay supply activity, perhaps involving a whole group of people. Such activity might have been distinct from individual and domestic tasks and could suggest that local production was no longer domestic. All data suggest a more complex social model of production that, in Mid Neolithic societies, might have changed from a family or domestic model to a nonformal or incipient-specialized one, following P. Rice (1981) and S. van der Leeuw (1984).

Chemical data are important in distinguishing different sub-groups of pottery related to their geographical setting. It can be inferred that Serra d'Alto pottery was produced in more than one site and that finished pots were not exchanged between different sites. Archaeometric data suggest a polycentric production based on a common technological background. The strong analogies in technological processes in different sites, the wide distribution of Serra d'Alto ware, the recurring vessel forms and decoration, clearly show a large network of middle-distance exchange of formal and technological models of productions, between many Neolithic sites located in different geographical areas.

\section{Acknowledgement}

This research was supported by the Consiglio Nazionale delle Ricerche through the Progetto Giovani - Agenzia 2000 (G004AC5) and by COFIN 2005 (prot. 2005043957_ 003).

\section{References}

Benac, A., 1975. Qualche parallelo tra la Daunia e la Bosnia durante il Neolitico. In Civiltà preistoriche e protostoriche della Daunia. Atti del Colloquio Internazionale di Preistoria e Protostorica della Daunia. Istituto Italiano di Preistoria e Protostorica, Florence, 145-148.

Cassano, S.M., 1993. La facies Serra d'Alto: intensificazione delle attività produttive e aspetti del rituale. Origini, XVII: 221253.

Cassano, S.M., Gratziu, C., Meucci, C., Marini, S. and Muntoni, I.M., 1994-1995. Analisi tecnologiche di impasti ceramici dal villaggio neolitico di Masseria Candelaro. Scienze dell'Antichità - Storia, Archeologia, Antropologia, 8-9: 39-57.

Cassano, S.M., Eramo, G., Laviano, R. and Muntoni, I.M., 2004. Analisi archeometriche delle ceramiche. In S.M. Cassano, A. Manfredini (ed.). Masseria Candelaro. Vita quotidiana e mondo ideologico in una comunità neolitica del Tavoliere. Claudio Grenzi Editore, Foggia, 221-249.
Dell'Anna, A. and Radina, F., 1994. Analisi mineralogica di alcuni manufatti ceramici neolitici provenienti dal territorio di Rutigliano (Bari, Puglia). In F. Burragato, O. Grubessi, L. Lazzarini (ed.). 1st European Workshop on Archaeological Ceramics. Università degli Studi "La Sapienza”, Rome, 441452.

Dell'Anna, L. and Laviano, R., 1988. A clay sedimentation picture of the Crati River Basin (Calabria, Southern Italy). Geologia applicata e idrogeologia, 23: 191-202.

Dell'Anna, L. and Laviano, R., 1991. Mineralogical and chemical classification of Pleistocene clays from the Lucanian Basin (Southern Italy) for the use in the Italian tile industry. Applied Clay Science, 6: 233-243.

Dell'Anna, A. and Laviano, R., 1994. Mineralogia e chimica di alcuni elementi ceramici neolitici della tipologia "Serra d'Alto". Materiale di partenza e sue trasformazioni mineralogiche. In F. Burragato, O. Grubessi, L. Lazzarini (ed.). 1st European Workshop on Archaeological Ceramics. Università degli Studi "La Sapienza", Rome, 461-475.

Di Martino, P., Farnetano, D., Grifa, C., Langella, A., Morra, V., Barattolo, F., Trojsi, G. and Tusa, S., 2006. Indagini mineralogiche e petrografiche su ceramiche neolitiche da Partanna (TP). In C. D’Amico (ed.). Innovazioni tecnologiche per $i$ beni culturali in Italia, Atti del Convegno dell'A.I.Ar. Pàtron Editore, Bologna, 131-144,.

Farnetano, D., Di Martino, P., Grifa, C., Barattolo, F., Langella, A., Morra, V., Trojsi, G. and Tusa, S., 2006. Tecniche paleontologiche per la caratterizzazione di ceramiche neolitiche ed argille affioranti presso Partanna (TP). In C. D’Amico (ed.). Innovazioni tecnologiche per $i$ beni culturali in Italia, Atti del Convegno dell'A. I.Ar. Pàtron Editore, Bologna, 119-130.

Franzini, M., Leoni, L. and Saitta, M., 1972. A simple method to evaluate the matrix in X-ray fluorescence analysis. $X$-ray Spectrometry, 1: 151-154.

Franzini, M., Leoni, L. and Saitta, M., 1975. Revisione di una metodologia analitica per fluorescenza X, basata sulla correzione completa degli effetti di matrice. Rendiconti della Società Italiana di Mineralogia e Petrologia, 31: 365-378.

Geniola, A., 1987. La cultura di Serra d'Alto nella Puglia centrale. In Atti della XXVI Riunione Scientifica dell'Istituto Italiano di Preistoria e Protostoria. Istituto Italiano di Preistoria e Protostorica, Florence, 771-781.

Geniola, A., Laviano, R. and Muntoni, I.M., 2005. Pottery Production in Late Neolithic Cult Sites of Santa Barbara and Cala Scizzo (Apulia, Southeast Italy). In M.I. Prudêncio, M.I. Dias, J.C. Waerenborgh (ed). Understanding people through their pottery. Proceedings of the 7th European Meeting on Ancient Ceramics. Instituto Português de Arqueologia, Lisbon, 89-101.

Heimann, R.B. and Maggetti, M., 1981. Experiments on Simulated Burial of Calcareous Terra Sigillata (Mineralogical 
Changes). Preliminary Results. In M.J. Hughes (ed.). Scientific Studies in Ancient Ceramics. BMOP 19, London, 163-177.

KreTz, R., 1983. Symbols for rock-forming minerals. American Mineralogist, 68: 277-279.

Laviano, R. and Muntoni, I.M., 2003. Pulo di Molfetta. Analisi archeometriche. In I.M. Muntoni. Modellare l'argilla. Vasai del Neolitico antico e medio nelle Murge pugliesi. Istituto Italiano di Preistoria e Protostorica, Florence, 143-159.

Laviano, R. and Muntoni, I.M., 2006. Provenance and technology of Apulian Neolithic pottery. In M. Maggetti, B. Messiga (ed). Geomaterials in Cultural Heritage. Geological Society of London, London, 49-62.

Laviano, R., Moresi, M., Muntoni, I.M. and Radina, F., 2008. Il territorio di Rutigliano: scelte tecnologiche nella produzione vascolare delle comunità neolitiche. In L. Damato (ed). Ceramica e archeometria in Puglia, Atti del Seminario di Studi, Rutigliano 22 Gennaio 2005. Rutigliano (Bari), 27-47.

Laviano, R. and Muntoni, I.M., in press. Produzione e circolazione della ceramica "Serra d'Alto" nel V millennio a.C. in Italia sud-orientale. In G. Bandini, B. Fabbri, S. Gualtieri (ed.). Le classi ceramiche: situazione degli studi. Atti della $10^{a}$ Giornata di Archeometria della Ceramica. Edipuglia, Baria.

LeOni, L. and SaitTa, M., 1976. Determination of yttrium and niobium on standard silicate rocks by X-ray fluorescence analyses. X-ray Spectrometry, 5: 29-30.

Lo Porto, F.G., 1989. L'insediamento neolitico di Serra d'Alto nel materano. Giorgio Bretschneider Editore, Rome.

Maggetti, M., 1981. Composition of Roman Pottery from Lousanna (Switzerland). In M.J. Hughes (ed.). Scientific Studies in Ancient Ceramics. BMOP 19, London, 33-49.

Maggetti, M., 1982. Phase Analysis and its Significance for Technology and Origin. In J.S. Olin, A.D. Franklin (ed). Archaeological Ceramics. Smithsonian Institution Press, Washington, 121-133.

Malone, C., 2003. The Italian Neolithic: A Synthesis of Research. Journal of World Prehistory, 17, (3): 235-312.

Messina, A., Russo, S., Borghi, A., Colonna, V., Compagnoni, R., Caggianelli, A., Fornelli, A. and Piccarreta, G., 1994. Il massiccio della Sila - Settore settentrionale dell'Arco Calabro-Peloritano. Bollettino della Società geologica italiana, 113: 539-586.

Morter, J. and ICELAND, H., 1995. Notes on an eastern Calabrian assemblage in the Stentinello tradition. In P. Vincenzini (ed.). The Ceramics Cultural Heritage. Techna, Faenza, 241-249.

MotTes, E., 2002. Influssi culturali peninsulari nel repertorio ceramico dei gruppi della cultura dei vasi a bocca quadrata del Trentino. In Atti della XXXIII Riunione Scientifica dell'Istituto Italiano di Preistoria e Protostoria. Volume 2. Istituto Italiano di Preistoria e Protostorica, Florence, 279-285.
Muntoni, I.M., 2003. Modellare l'argilla. Vasai del Neolitico antico e medio nelle Murge pugliesi. Istituto Italiano di Preistoria e Protostoria, Florence.

Muntoni, I.M., Laviano, R. and Radina, F., 2006. Materie prime e tecnologia di produzione della ceramica "Serra d'Alto" nelle Murge pugliesi. In B. Fabbri, S. Gualtieri, M. Romito (ed). La ceramica in Italia quando l'Italia non c'era. Atti della $8^{a}$ Giornata di Archeometria della Ceramica. Edipuglia, Bari, 89-97.

Muntoni, I.M., Acquafredda, P. and Laviano, R., 2007. Early and Middle/Late Neolithic pottery production in Northern Calabria (Italy): raw material provenance, paste preparation and firing techniques. In S.Y. Waksman (ed). Archaeometric and Archaeological Approaches to Ceramics. Papers presented at EMAC '05, 8th European Meeting on Ancient Ceramics, Lyon 2005. British Archaeological Reports Int.S. 1691, Oxford, 41-48.

Muntoni, I.M., Eramo, G. and Laviano, R., in press. Production of Mid-Late Neolithic "Serra d'Alto" ware in the Bradanic Trough (South Eastern Italy). In K.T. Biró, V. Szilágyi, A. Kreiter (ed.). Vessels inside and outside. Proceedings of the 9th European Meeting on Ancient Ceramics. Hungarian National Museum, Budapest.

Rice, P.M., 1981. Evolution of Specialized Pottery Production: A Trial Model. Current Anthropology 22 (3): 219-240.

Ridola, D., 1924-1926. Le grandi trincee preistoriche di Matera. La ceramica e la civiltà di quel tempo. Bullettino di Paletnologia Italiana, XLIV: 97-122; XLV: 85-98; XLVI: 134-174.

Sella, M., Turci, C. and Riva, A., 1988. Sintesi geopetrolifera della Fossa Bradanica (Avanfossa della catena appenninica meridionale). Memorie della Società Geologica Italiana, 41: 87-107.

Trump, D.H., 1966. Skorba. Society of Antiquaries of London, London.

Van DeR LeEuw, S.E., 1984. Dust to dust: a trasformational view of the ceramic cycle. In S.E. Van Der Leeuw, A.C. Pritchard (ed.). The many dimensions of pottery. University of Amsterdam Press, Amsterdam, 707-774.

Williams, J.L.L., 1980. A Petrological Examination of the Prehistoric Pottery from the Excavations in the Castello and Diana Plain of Lipari - An interim Report. In L. Bernabò Brea, M. Cavalier. Meligunis Lipára IV. L'acropoli di Lipari nella preistoria. S.F. Flaccovio Editore, Palermo, 845-868.

Williams, J.L.L. and LEVI, S.T. 2001. The petrographic characterisation of Neolithic pottery fabrics from the excavations in the Acropolis and Diana plain of Lipari-Capri, Serra d'Alto and Diana. In M.C. Martinelli, U. Spigo (ed.). Studi di Preistoria e Protostoria in onore di Luigi Bernabò Brea. EDAS, Messina, 277-304.

ArcheoSciences, revue d'archéométrie, 32, 2008, p. 125-135 